\title{
MEDIJSKE KOMPETENCIJE I SAMO-SOCIJALIZACIJA U KONTEKSTU NOVIH MEDIJA ${ }^{1}$
}

Internet otvara pristup medijskim ponudama koje mogu biti individualno oblikovane više nego drugi masovni mediji, zato se moramo zapitati kako učiti individualne metode rada sa medijskim ponudama i da li izmenjeni oblici medija utiču na procese medijske socijalizacije. Ove moguće uticaje nadalje posmatramo kao oblike samo-socijalizacije.

Koncept samo-socijalizacije može se staviti u različite kontekste prethodnih studija socijalizacije, ako je, kao i uvek, usmeren na nezavisnost subjekata. Teorije socijalizacije se mogu razlikovati prema načinu na koji mere aspekte samo-socijalizacie i socijalizacije koju realizuje neka druga osoba (nastavnik, roditelj, vršnjaci). Što više prihvatamo mogućnosti direktnog spoljašnjeg uticaja, uputstava i intervencija na subjekat, sve više su naglašeni procesi socijalizacije koje realizuje neka druga osoba. Nasuprot tome, što više ističemo procese samoorganizovanja, samo-regulisanja i samo-konstruktivnosti, sve više na umu imamo aspekte samo-socijalizacije.

Upravo u oblasti socijalizacije u suočavanju sa novim medijima, možemo sada ukazati na činjenicu da su nove generacije sve više prepuštene same sebi i stoga se one socijalizuju nezavisno (samostalno). Upotreba medija kao samo-socijalizacije, znači da oni koji su socijalizovani, oni upravljaju izborom medija i medijskog sadržaja, relativno autonomno odlučuju o vremenu i mestu pristupa medijima i samostalno izgrađuju značenje medijskih sadržaja u procesu prijema, koji se takođe ogleda nezavisnom izgradnjom ili razvojem značenja tih sadržaja. To se odnosi i na aspekt interaktivnosti novih medija, odnosno individualnog raspolaganja sa medijskim sadržajem. Iz ovoga proizilazi da: mogućnost intervencije i organizacije za korisnike povećava autonomiju u radu sa medijima. Za razliku od starijih, kako se često kaže, mlađe generacije daju veću vrednost samostalnom određivanju izbora medijskih sadržaja, određivanju vremena i oblika u kom će se koristiti.

Novi mediji su postavili zadatak za medijsku pedagogiju da razmisli o pretpostavkama, procesima i uslovima usvajanja medijske kompetencije. To može da se ostvari kroz diskusiju o odnosu između interaktivnosti novih medija i samo-socijalizacije.

Ključne reči: novi mediji, samo-socijalizacija, medijska pedagogija, medijske kompetencije, internet

pedagozi@ff.uns.ac.rs Rad je nastao kao rezultat istraživanja u okviru Projekta Digitalne medijske tehnologije i društveno-obrazovne promene (Projekat br. 47020) koji se realizuje uz finansijsku podršku Ministarstva za nauku i tehnološki razvoj Republike Srbije za period 2011-2014. 


\section{UVOD}

Kao i u mnogim drugim oblastima naučnog istraživanja medija, i istraživanja i teorije novih medija i internet komunikacije su morale da se bore sa problemima jednostranosti i skraćivanja: s jedne strane se odvija brz razvoj novih mogućnosti komunikacije putem kompjutera, koje su usko povezane sa novim tehnološkim dostignućima i novim oblicima medija. Za ovu dimenziju novih medija postojao je i postoji u zadnje vreme izraz Web 2.0, koji označava kvalitet participacije i stvaranja ponuda za korisnike na internetu. Sa druge strane u mnogim naučnim radovima o internet komunikaciji raste svest da se medijske mogućnosti participacije i stvaranja ne smeju poistovećivati sa njihovim realizovanjem i konzumacijom od strane korisnika, već da ovde zjapi jedna manje-više velika praznina. Za dimenziju sposobnosti i spremnosti na stvarno korišćenje novih mogućnosti medija stoji centralni pojam medijske kompetencije, koji bi opet trebalo smatrati osnovom procesa mobilnog učenja u okviru novih medija. Približavanje pitanjima medijske kompetencije i takozvanom „E-Learning-u“ u okviru novih medija, zahteva razjašnjavanje veze medijskih kompetencija i novih medija, a pre svega odnos mogućnosti stvorenih kroz nove medije i potencijala realizovanih u praktičnom rukovanju pojedinaca sa njima.

Ne mala teškoća u objašnjenju ove veze se sastoji u tome, što se ona odnosi na dva široko rasprostranjena izraza, koji su veoma nejasno definisani: kompetencija tj. medijska kompetencija i Web 2.0. Potrebno je, kao i uvek u nauci, nešto vremena da se novi razvoji i nove veze sagledaju i da se o njima razmisli. Ako se u kontekstu Web 2.0 kaže, ,normativna referentna tačka za unapređivanje medijske kompetencije bi trebalo da bude povećanje kvaliteta života u društvu koje uči“ (Gapski/Gräßer 2007:11), onda će to sigurno naići na opšte odobravanje - ali je isto teško to opovrgnuti, jer nije jasno šta se time misli. Najpre se radi o tome da se opišu novi razvoji u vezi sa Web 2.0, da bi se onda postepeno razjasnio odnos ovih novih oblika medijske komunikacije i odgovarajućih medijskih kompetencija.

U međuvremenu E-Learning sve više postaje deo svakodnevice na fakultetima. Aktuelna sistematika Michaela Kerresa i Alexa Nattlanda pravi razliku između karakteristika Web 1.0 i Web 2.0 formata (2007). „E-Learning 1.0“ znači zatvoreno okruženje za učenje kao ostrvo na internetu sa sadržajima i alatima datim na raspolaganje. Nastavnik oprema ostrvo ovim sadržajima i alatima, koje učenik potom koristi. Nasuprot tome „E-Learning 2.0“ znači otvoreno, umreženo okruženje za učenje kao portal na internetu sa sadržajima i alatima koji stoje na raspolaganju. Nastavnik postavlja putokaz, a učenik oblikuje svoje lično okruženje za rad i učenje. Sigurno je uzbudljivo pitanje u kojoj meri novi mediji mogu promeniti procese učenja od rukovanja generalizovanim tekstovima raširenim preko masovnih medija u rukovanje tekstovima kojima se može individualno raspolagati i koji se mogu individualno uobličiti. U obrazovnom procesu sigurno ima granica, pre svega u pogledu mogućnosti provere i ozbiljnosti korišćenih izvora. 
U jeku brzih i gotovo nepreglednih promena, kada sve mora ostati otvoreno i spekulativno, trebalo bi razjasniti osnove odnosa medijske kompetencije u kontekstu Web 2.0 sa medijsko-sociološkog stanovišta. Pritom težište nije na konkretnom određivanju utvrđenih ključnih kvalifikacija za rukovanje novim medijima, nego na pitanju, kako da zamislimo procese učenja i socijalizacije u rukovanju novim medijima. Dakle radi se pre svega o razmatranju nekih osnova koje su potrebne da bi se obradila pitanja usvajanja kompetencija u rukovanju novim medijima (Andevski, Vučković 2012).

\section{O POJMU MEDIJSKE KOMPETENCIJE}

Pojam medijske kompetencije se na različite načine provlači kroz gomilu analiza i debata u različitim oblastima: ne samo u nauci (biologija, lingvistika, sociologija, psihologija i pedagogija), nego i u politici, pravu ili privredi. Razumljivo da pojam tako postaje nejasan i višeznačan te stoga treba specifikovati, na šta se pod njim, u određenom kontekstu, podrazumeva. Od velike pomoći je da se najpre uopssteno osmotri pojam kompetencije. Za razliku od pojma medijske kompetencije, širi pojam kompetencije ima dužu istoriju. Ova istorija razvoja teorija kompetencije se može podeliti u tri faze: 1. lingvističko definisanje pojma kompetencije tokom 70-ih godina, 2 . njegovo uvođenje $u$ različite teorije razvoja $i$ socijalizacije i 3. njegova upotreba u sociološkim analizama socijalizacije i društva tokom 80-ih. Istraživanja okrenuta teorijama kompetencije su morala da se suoče sa mnogim problemima, već oko tačnog značenja pojma kompetencije, koji se deli u pomenute tri faze, postojale su mnoge nejasnoće.

U društvenim naukama je pojam kompetencije uobičajen u poređenju sa performansom iz lingvistike Noama Čomskog: jezička kompetencija prema Čomskom predstavlja intuitivno poznavanje pravila kojim raspolažu subjekti. Performans obuhvata ograničavajuće faktore upotrebe jezika. Jezička kompetencija se opisuje gramatikom jednog jezika. Kada deca uče jezik, moraju raspolagati generativnom gramatikom tj. metodom, ,(...) kako da se stvori prilagođena gramatika od datih primarnih jezičkih podataka" (Chomsky 1972: 41). Pritom se radi o urođenim, individualnim predispozicijama, koje se nalaze na sinhronom nivou.

Nasuprot tome, u strukturno-genetičkim teorijama kompetencije, u središtu je pitanje konstruktivnog usvajanja univerzalnih kompetencija. Radi se o teorijama usvajanja opštih kognitivnih, socijalnih i moralnih kompetencija prema tradiciji Jeana Piageta. Osnova ove tradicije je konstruktivizam, koji se striktno ograđuje od nativizma Čomskog: on smatra da subjekti u jednom aktivnom procesu konstrukcije najpre grade strukture sopstvenog unutrašnjeg sveta, kao i urođenog $\mathrm{i}$ socijalnog spoljnog sveta. Pritom se obrazuju opšte subjektivne kompetencije koje nisu stvorene nativistički, kao kod Čomskog, već kontruktivistički: upravo ova okolnost znači osetnu promenu pojma kompetencije u drugoj fazi njegovog razvitka. Kompetencija od sinhronog postaje dijahroni konstrukt, usko povezan sa intrasubjektivnim procesima konstrukcije. Strukturno-genetičke teorije kompe- 
tencije ne uključuju toliko procese učenja i razvoja, već izrađuju strukturno-analitičke opise stadijuma kognitivnog, socijalnog i moralnog razvoja (Sutter 1994).

Fokusiranje na intrasubjektivne konstrukcije se sa prihvatanjem pojma kompetencija menja u sociološko istraživanje socijalizacije. Pored „lingvističkog okreta“ (linguistic turn) u društvenim naukama, strukturno-genetičke teorije kompetencije su podstakle Jürgena Habermasa da preuzme pojam kompetencije u teoriji povezivanja socijalizacijsko- i društveno-teorijskih perspektiva. Na socijalizacijsko-teorijskom nivou se radi o povezivanju sociološke teorije stvaranja Ja-identiteta sa psihološkim teorijama kognitivnog, socijalnog i moralnog razvoja (između ostalog sa onima od Piageta, Selmana i Kohlberga). Pritom je „vodič“ bilo mišljenje da subjekti razvijaju svoje kompetencije u socijalnim interakcijama. Habermas u ovom kontekstu govori o kompetenciji uloga, kompetenciji interakcije, ali i o komunikativnoj kompetenciji (Habermas 1995). Subjektivne kompetencije se uvek usvajaju u okviru razvoja komunikativne kompetencije, a ova opet kao preduslov ima stalno učešće u procesima komunikacije. Time se obrće razvojno-psihološki odnos između subjektivnih i socijalnih struktura: procesi socijalnih interakcija su ti koji ubrzavaju i organizuju proces stvaranja subjektivnih kompetencija.

Pomenuta istraživanja teorija kompetencija su bila izložena raznim kritikama i ovde ćemo se podsetiti na neke od njih. One se okreću protiv razvojno- i socijalizacijsko-teorijskog preuzimanja pojma kompetencija: pojam kompetencije je prvo nativistički, sinhrono i individualno upotrebljen i stoga nije pogodan za ovo preuzimanje. Pojmom kompetencije se prema Čomskom opisuje samo priroda intuitivnog poznavanja pravila jezika, ne i njegovo usvajanje. Kompetencija je u ovom smislu biološki zasnovan, statični koncept. Stoga se s dobrim razlozima mogu izneti sumnje protiv prenošenja ovog sinhrono upotrebljenog lingvističkog instrumenta za opisivanje u subjektivne teorije usvajanja. Sa lingvističkog stanovišta kompetencija u teorijama usvajanja se nedopustivo brka sa konotacijama sposobnosti ili veštine i povezuje sa elementima stranim pojmu (nešto poput „komunikativne" kompetencije). Ova prva opšta tačka se može svrstati uz sledeće dve: kao drugo, sa pojmom kompetencije su povezani posebni problemi metoda, jer su samo performansi direktno empirijski dostupni i iz ovih podataka se mora indirektno zaključivati o kompetencijama. Teorije kompetencije na kraju ostaju spekulativne. Kada se naime pojave razlike između pretpostavljenih kompetencija i performansi koje se mogu osmotriti empirijski, nastaje obilje problema, što naročito dolazi do izražaja u empirijskom proučavanju morala Lawrencea Kohlberga (1983). Na osnovu stadijuma psihološkog razvoja morali su se istražiti razni faktori koji određuju performanse, a koji ubrzavaju ili sputavaju transformaciju pretpostavljenih kompetencija. Ovako se pak teorija kompetencije sama ne može empirijski opovrgnuti. Kohlberg (1983) priznaje da centralna teorijska shvatanja mogu da se modifikuju samo na osnovu teorijskih razmišljanja. Treće, subjektivne strategije usvajanja, ali pre svega socijalni uslovi razvoja obrazovanja subjekta ne mogu biti objašnjene teorijom kompetencije. Na kraju je statični pojam kompetencije upotrebljen u kontekstu teorije usvajanja. Ovo je vodilo tome, da 
se bavilo strukturno-analitičkim opisima pretpostavljenih kompetencija, dakle rezultatima učenja, a ne procesima i kontekstima učenja tj. usvajanjem kompetencija.

S ovim skeptičnim zamerkama teorijama kompetencije etabliranim u 70-im i 80-im bi trebalo da postane jasno, da kod određivanja pojma medijske kompetencije treba paziti na pojedine tačke, da se stare greške ne bi ponavljale. Naročito se ne bi trebalo ograničiti samo na rezultate individualnih procesa učenja. Dalje, ne bi trebalo zapostaviti ni socijalne uslove, kao ni procesualnu dinamiku procesa razvoja i socijalizacije u polju medijskih kompetencija. Poenta je u sledećem: mogu se zastupati ove ili one medijske kompetencije, ali da li se time zastupa nešto razumno i validno, pokazaće se tek onda kada se bude moglo razjasniti kada i pod kojim uslovima se zastupane kompetencije obrazuju. Na ovaj način se dospeva do empirijski sadržajnog pojma medijske kompetencije, a da se iz vida ne izgube neizbežne granice ovog pojma.

Pojam medijske kompetencije, prema Baacke-u (1996) i Theunert-u (1999) može imati veoma različita značenja (Sutter/Charlton 2002):

- Razumeti medije: medijska kompetencija se može odnositi na razumevanje medijskih ponuda.

- Vladati medijima: medijska kompetencija se može odnositi na veštinu rukovanja medijskim aparatima.

- Upotrebiti medije: medijska kompetencija se može odnositi na efektivnu upotrebu medija u rešavanju školskih i poslovnih zadataka. Može se iskazati i u sposobnosti da se pomoću medija planira slobodno vreme i u njemu uživa.

- Stvarati medije: medijska kompetencija se može odnositi na sastavljanje medijskih ponuda.

- (Pr)Ocenjivati medije: medijska kompetencija se konačno može odnositi na funkcije medijskog sistema. Medijska kompetencija u ovom smislu podrazumeva sposobnost da se obuhvate društveni odnosi i (pr)oceni sopstveno delanje pod normativnim i etičkim aspektima.

Sigurno da ove opšte medijske kompetencije igraju centralnu ulogu i u oblasti rukovanja novim medijima. Ali pitanje, koje ćemo u nastavku razmatrati, ide dalje i nije prožeto pojmovima medijske kompetencije: da li promenjene forme novih medija menjaju način na koji se medijske kompetencije usvajaju? Principijelno, može se pretpostaviti da povećane mogućnosti povratne informacije, intervencije i organizacije, koje novi mediji nude korisnicima, imaju uticaj na medijsku socijalizaciju, vrstu usvajanja medijske kompetencije. Ako je manje jasno određeno za sve, a više individualno raspoloživo i podložno uobličavanju, onda bi procesi samosocijalizacije morali igrati sve važniju ulogu. Sledeća razmišljanja se kreću oko odnosa povećane interaktivnosti, kojom se opisuje diskutabilna promena medija, ali i Teorije samosocijalizacije. 


\section{WEB 2.0 I INTERAKTIVNOST NOVIH MEDIJA}

Debata oko Web 2.0 se može staviti u kontekst jedne obimne diskusije, šta bi to trebalo da bude novo u novim medijima i kako to primereno opisati. Pritom su važnu ulogu imala poređenja sa starim, etabliranim masovnim medijima. Naročito je televizija kao glavni medij bila i jeste jednostrani oblik komunikacije bez ikakve povratne informacije, koji uspešno sprečava društvene, interaktivne veze između medijskih aktera i recipijenata. Masovna komunikacija se kroz posrednost tehnike oslobađa ograničenja interakcije, ona teče jednostrano i sa malo povratnih informcija (Luhmann 1996). Poseban uspeh sistema masovnih medija se sastoji u tome što komunikaciju širi po celom društvu. Uspeh širenja komunikacije po celom društvu je omogućen jednostranim oblikom komunikacije, koja teče od pošiljaoca ka nepreglednom krugu heterogenih i anonimnih adresanata, koji čine raštrkanu publiku.

Za razliku od masovnih medija koji nisu interaktivni, novi mediji se zbog novih tehnoloških mogućnosti označavaju kao ,interaktivni“. Time se može označiti promena od masovnog medija bez povratne informacije u medij koji otvara razne mogućnosti intervencije, organizacije i povratnih informacija. Novi oblici tehnološki otvorene medijske komunikacije se označavaju kao „interaktivni““ odnosno kao interaktivnost novih medija, ovde se posebno radi o novim mogućnostima povratne informacije i organizacije za korisnike. Označavanje novih medija kao ,interaktivni“, usmerava analizu novih medijskih oblika komunikacije ka poređenjima sa direktnim face-to-face interakcijama (Neuberger 2007; Rörig 2006).

Postoje dva pristupa novim medijima, koje bi teorija medijske kompetencije morala da uzme u obzir: prvi pristup se odnosi na problematiku forme medija i on pita kako se nove forme medijske komunikacije mogu primereno opisati. Drugi pristup ne stavlja toliko nove tehničke razvoje i nove tehničke forme u središte pažnje, koliko subjektivna opažanja novih medija i načine rukovanja novim medijima (Bucher 2004). Time se u naučnom proučavanju medija nastavlja odavno etablirano suprotstavljanje mediocentričnih perspektiva i perspektiva okrenutih recepciji tj. korisnicima. Iz duge istorije ovog suprotstavljanja u proučavanju masovne komunikacije znamo da oba problema moramo povezati jedan s drugim, medijsku problematiku forme i problem subjektivnog rukovanja medijima. Ovo se odnosi na oblast novih medija. Nove forme medija pokazuju šta je moguće, a subjektivni načini korišćenja pokazuju šta se od mogućeg može realizovati.

Novi oblici internet komunikacije otvaraju kao prvo individualne pristupe ponudama medija, a kao drugo povećane individualne mogućnosti intervencije i organizacije. Ljudi od recipijenata koji posmatraju postaju korisnici koji stvaraju tekst i organizuju. Postoje novi putevi informacije, komunikacije i zabave. $U$ oblasti informacije su naročito upadljivi prostori za komunikaciju tipa ,wiki“" $\mathrm{i}$ to pre svega internet enciklopedija Wikipedia (Mehler/Sutter 2008). Ovaj prostor za komunikaciju korisnicima nudi mogućnosti učešća ekstremno niskog praga. U 
principu svi mogu pisati i ispravljati tekstove. Ovaj prostor pruža mogućnost da se tekstovi kooperativno pišu, ispravljaju i aktivno ažuriraju. Za razliku od funkcije generalizacije ponude medija u oblasti masovnih medija ovde je upadljivo da se tekstovi doduše šire, ali su i uvek promenljivi. Za razliku od knjiga, koje sve nude jedan identičan tekst, Wikipedia nudi - uvek samo potencijalno - promenljive tekstove. Iznenađujuće je da Wikipedia uprkos ovim mogućnostima organizacije, a time i ometanja i zloupotrebe, pruža i kvalitetne informacije, pri čemu je evidentno da se mogućnosti učestvovanja mnogo manje koriste nego mogućnosti recepcije.

Sigurno je logično, ali tek prvi korak, opisati ove razvoje kao pomeranja i raspadanje granica, naročito granica između producenata $\mathrm{tj}$. autora $\mathrm{i}$ recipijenata tj. korisnika i granica između privatnog i javnog. Medijska sociologija pokušava da rasvetli takve aspekte novih oblika medijske komunikacije. Ovde pored opšte poznatih mogućnosti povratne informacije, intervencije i organizacije treba pomenuti i druga specifična obeležja: poput anonimnosti učesnika i s time povezane depersonalizacije komunikacije (Krämer 2000). U internet komunikaciji se često radi, ne o vezama između konkretnih osoba koje se opažaju, identifikuju kao osobe, nego o intertekstualnosti, o vezama između tekstova. Pismena forma teksta $\mathrm{u}$ komunikaciji stvara nepremostivu razliku prema usmenom razgovoru utoliko što korisnici nisu u interakciji sa osobama, nego sa tekstovima tj. simboličkim reprezentacijama. Osobe postaju simboličke reprezentacije.

U ovom kontekstu i čet, koji je ocenjen kao veoma interaktivan, gubi svoju nevinost. Pismeno vođeni razgovori se $\mathrm{u}$ pogledu sinhronizovanosti udela mogu približiti socijalnim interakcijama, ali se uvek može opaziti tehnološko omogućavanje i prenos komunikacije (Beißwenger 2005; Tipp 2008). Čak i kada se pisani unosi u instant-messaging sistemima pojave direktno na ekranima adresanata, istovremena recepcija komunikacije nije sigurna. Adresati se npr. mogu baviti sastavljanjem sopstvenog unosa. Ono što u usmenom razgovoru (i preko telefona) vodi nerazumljivoj kakofoniji, ovde je normalna pojava: istovremena produkcija iskaza. Postupak saopštavanja i procesi recepcije tj. razumevanja kao i dodatne komunikacije su razdvojeni, i ovde komunikativna tehnologija ubedljivo dolazi do izražaja. Kada se na ovaj način povećaju kontingencija i netransparentnost komunikacije, za više osoba koje učestvuju u četu mogu nastati različiti tokovi. Ovde se radi samo o tome da se na primeru objasni na kojim posmatranjima i analizama bi počivala debata o medijskim kompetencijama u kontekstu Web 2.0 sa medijsko-sociološkog stanovišta.

Izgleda poznato, ako se s ovim uporedi primarni uspeh vodećeg medija, televizije. Gledano sa stanovišta medija, nesumnjivo postoji duboka promena medija od jednostranih masovnih medija u umrežene ,interaktivne“ medije, gledano sa stanovišta korisnika čini se da su s tim povezane nove mogućnosti malo promenjene: Wikipedia ili YouTube na primer, izgledaju više kao masovni mediji, jedino što sadržaje stvaraju i oblikuju pojedini korisnici. Ono što bi još moglo biti uzrok velikog zaziranja od aktivnog učešća, poput zloupotrebe ličnih podataka, 
ta razlika između medijski raspoloživih potencijala aktivnog učešća i nedovoljne realizacije ovih potencijala, jeste za naučno proučavanje medija od velikog značaja. Ništa manje nije važno pitati, u kojoj meri bi trebalo isključiti pitanja medijske kompetencije iz novih medija i u kojoj meri bi trebalo imati u vidu postojeća pitanja medijske kompetencije u kontekstu masovnih medija.

Kao i u oblasti istraživanja medija, potrebna nam je strategija istraživanja koja izbegava jednostranost. Jednostranost preti kada se fokusira samo na problem forme medija ili samo na kontekste i procese subjektivnog načina rukovanja. Zahtev da se ne posmatra samo problem forme novih medija nego i konteksti i načini rukovanja novim medijima, se postavlja i u oblasti interaktivnosti. A ovde ne vrebaju opasnosti samo u fokusiranju na problematiku forme medija. Jednostranostima vodi i kada se misli da se odlike interaktivnosti mogu analizirati pre svega u praktičnom radu sa internetom, ili kada se tvrdi da je Web 2.0 određena vrsta opažanja i korišćenja interneta.

Mogućnosti nove komunikacije preko kompjutera ne treba posmatrati samo na nivou forme medija i subjektivnog opažanja i korišćenja, već i u datim socijalnim kontekstima. Nove mogućnosti onlajn-komunikacija i onlajn-grupa su „uvijene“ u socijalne kontekste $\mathrm{i}$ što se tiče njihovih prednosti i mana, zavise od ovih konteksta (Matzat 2005): „Ako je interakcija u okviru onlajn-grupe povezana u društvenu mrežu, koja postoji i u oflajn-svetu, onda se to naziva socijalno usađivanje onlajn-interakcije u mreže oflajn-sveta" (isto, s. 176). Ovo usađivanje igra centralnu ulogu u organizovanju i poboljšavanju onlajn-interakcija. Ovde su tipični problemi mogućnosti kontrole ili takođe građenja poverenja. Za rešavanje takvih problema često je od pomoći dodatno korišćenje mogućnosti direktnih interakcija van interneta. Procesi učenja i usvajanja kompetencija zasnovani na internetu zavise od socijalnih uslova, koji se mogu organizovati i oblikovati.

\section{(SAMO)SOCIJALIZACIJA U RUKOVANJU NOVIM MEDIJIMA}

Ako treba detaljno objasniti kako se interaktivnost realizuje u relaciji novih formi medija i njihovog korišćenja, tako je fundamentalno smatrati, da internet daleko više od masovnih medija otvara pristup medijskim ponudama, koji se individualno može uobličiti. Stoga se može postaviti pitanje, kako se uče ovi novi individualni načini ophođenja sa medijskim ponudama, da li promenjene forme medija imaju uticaja na procese medijske socijalizacije. Ako treba posmatrati uticaje, oni bi morali biti u vidnom polju kao povećani značaj samosocijalizacije.

Opšti pojam samosocijalizacije se može staviti u različite kontekste dosadašnjeg istraživanja socijalizacije, ako kao i uvek cilja na spremnu samostalnost subjekata (Dollase 1999; Veith 2002; Zinnecker 2000). Teorije socijalizacije se mogu razlikovati po tome kako odmeravaju aspekte samosocijalizacije i socijalizacije koju vrši neko drugo lice. Što se više usvajaju direktne spoljašnje mogućnosti uticaja, instrukcije i intervencije na subjektu, to se više naglašavaju procesi socijalizacije koju vrši drugo lice. Nasuprot tome, što se više naglašavaju procesi 
samoorganizacije, samoregulacije i samokonstruktivnosti, to se više imaju u vidu aspekti samosocijalizacije.

Odnos samosocijalizacije i korišćenja medija tj. medijske kompetencije nije nov i u širokom polju istraživanja masovne komunikacije je upravo podrobno opisan i prodiskutovan. Subjekti nisu, kako razna istraživanja okrenuta recepciji pokazuju, pasivno i bespomoćno ostavljeni uticajima medija, već oni individualno i samostalno rukuju medijskim ponudama. Ovaj aspekt medijske socijalizacije bi se morao izvoditi korak po korak prema istraživanjima medija usmerenih na medijske prinude i dejstva. Ophođenje sa medijima zavisi od spoljnih konteksta i počiva na subjektivnim pretpostavkama. Novi naraštaji moraju u svojoj socijalizaciji prvo usvojiti kognitivne, jezičke i socijalne veštine da bi mogli rukovati medijima. Rukovanje medijima određuju socijalni uslovi i biografske situacije. Recipijenti opažaju medijske ponude u odnosu na lično relevantne teme i određene probleme, i manje ili više svesno svoju životnu situaciju dovode u vezu sa medijskim ponudama. Upravo u oblasti masovnih medija konstruktivističke teorije socijalizacije medija vide mnoge mogućnosti za to da novi naraštaji sami ili u saradnji sa drugim osobama samostalno upravljaju procesom recepcije i rukovanjem medijima.

Teorije samosocijalizacije mogu počivati na opštem viđenju da rastu mogućnosti i zahtevi da se građenje sopstvene ličnosti samostalno uobličava (Hurrelmann 2002). Upravo u oblasti socijalizacije u rukovanju novim medijima se sad može ukazati na to da su nova pokolenja sve više prepuštena sama sebi i stoga se sve više sama socijalizuju (Fromme et.al 1999). „Upotreba medija kao samosocijalizacija znači“, kako to Daniel Süss formuliše, „da oni koji se socijalizuju sami upravljaju izborom medija i medijskih sadržaja, relativno autonomno odlučuju o vremenu i mestu medija i samostalno konstruišu značenje medijskih sadržaja u procesu recepcije“ (2004: 67). Kao što vidimo, ovo je delimično formulisano za ophođenje prema masovnim medijima, kod kojeg se radi o recepciji datih sadržaja, čije se značenje samostalno razvija. Ali delimično vidimo, da se odnosi i na aspekt interaktivnosti novih medija, dakle individualno raspolaganje medijskim sadržajima, a iz diskusije o interaktivnosti novih medija jasno proizilazi: mogućnosti intervencije i organizacije za korisnike povećavaju autonomiju u rukovanju medijima. Za razliku od starijih, kako se često kaže, mlađa generacija polaže veću vrednost na to da sama odredi kojim medijskim ponudama, kada i u kojoj formi će rukovati.

Da li se ovde dugoročno povezuju dalekosežna promena medija sa osnovnim promenama navika korišćenja, ostaje još da se vidi. I mlađi ljudi postaju stariji i moguće da rado razgovaraju o masovnim medijima na sasvim tradicionalan način. Osim toga: to što povećana interaktivnost novih medija stoji na raspolaganju kao potencijal, još ne znači, da i ovaj potencijal menja. Dogod subjekti u svojoj medijskoj socijalizaciji koriste interaktivne mogućnosti novih medija, sve više će savladavati procese samosocijalizacije, jer ranije utvrđene smernice stoje na raspolaganju. 
Ako se pogledaju opšte osnove i uslovi E-Learning-a u kontekstu Web 2.0, postaje jasno da se ovde radi o slučaju koji je pun pretpostavki i zahteva, koje je verovatno moguće realizovati samo u specijalnim oblastima obrazovanja na fakultetima (Krappmann 2002). Kao što je u tekstu već opaženo, „E-Learning 2.0“ znači da oni koji uče sami stvaraju okruženje za učenje i radno okruženje. Za ovo nisu neophodne samo obimne kompetencije, nego i ogromna motivacija. Moraćemo videti da li takvi visoko motivisani aktivni korisnici novih medija čine ograničenu grupu, za koju su prikačene određene oblasti „E-Learninga-a 2.0“, ili da li će se odnos aktivnih i pasivnih korisnika u budućnosti promeniti u pravcu aktivnog učešća. Takođe, tek treba da saznamo, kako i u kojoj meri će oni koji uče promeniti upotrebu datih sadržaja u ličnu konfiguraciju okruženja za učenje.

Već navedeni primer Wikipedije, iz oblasti komunikacije zasnovane na internetu, može se iskoristiti za prvu procenu takvih mogućih razvoja. Ovde bi trebalo postaviti pitanje, šta to uopšte motiviše korisnike da aktivno učestvuju u kooperativnoj produkciji tekstova, ispravljanju tekstova $\mathrm{i} u$, sa tim povezanim procesima ispitivanjima i diskusije. Ove motivacije su, s obzirom na ukupan broj korisnika, očigledno relativno malo razvijene. Pa ipak je mnogim osobama sigurno interesantno i isto tako korisno da aktivno učestvuju u jednom takvom prostoru za komunikaciju. Tako za studente može biti veliki podsticaj da kroz aktivno učešće u kolaborativnim ,radnim prostorima“ na internetu pobegnu od stega predavanja u učionicama sa određenim prostorom i vremenom. U velikim prostorima za komunikaciju kao Wikipedia se može steći status eksperta sa odgovarajućom reputacijom i privilegijama. U svemu tome čini se da pre svega intrinzični motivi korisnika, ovde igraju bitnu ulogu, posebno ako se raduje rešavanju problema, sukobima, kolektivnim poboljšanjima itd.

I onda kada iz osnovnog rasuđivanja na teorije samosocijalizacije gledamo skeptično (Krappmann 2002), moramo priznati da procesi usvajanja opisani samosocijalizacijom sve više dospevaju u centar pažnje, ako se otvore povećane mogućnosti izbora, povratne informacije, organizacije i intervencije u rukovanju medijima. Za medijsku pedagogiju time nastaju problemi povišene nesigurnosti i netransparentnosti u procesu usvajanja medijske kompetencije. Usvajanje medijske kompetencije je sve više slučaj samokontrolisanog rukovanja mladih sa novim medijima, a sve manje slučaj planirane i usmerene instrukcije i posredovanja. Novi mediji medijsku pedagogiju stavljaju pred zadatak da uravnoteži odnos samosocijalizacije i socijalizacije koju vrši drugo lice. Na taj način se i značaj različitih medijskih kompetencija može dalje objasniti.

\section{ZAKLJUČAK}

Uravnoteženje odnosa samosocijalizacije i socijalizacije koju vrši drugo lice pri usvajanju medijske kompetencije u rukovanju novim medijima mora na osnovu postojećih razmišljanja započeti na najmanje tri nivoa koje međusobno treba povezati: nove forme medija, subjektivni procesi opažanja i korišćenja novih 
medija, kao i socijalni konteksti internet komunikacije. Ova tri nivoa su važna i za teoriju usvajanja medijske kompetencije u oblasti masovnih medija (Sutter 2002). U oblasti kako starih tako i novih medija postavljaju se pitanja o uticaju forme medija, o potencijalima autonomije i organizacije recipijenata i korisnika, kao i o značaju različitih socijalnih konteksta. Nova istraživanja i sistematizacije analiza interaktivnosti novih medija pokazuju relevantnost ova tri nivoa, kada se traže integrisane, obimne koncepcije interaktivnosti (Neuberger 2007). Tako se na primer razlikuju dimenzije medijskih komunikativnih tehnologija, različitih komunikativnih konteksta i načina opažanja korisnika.

Pored ovih diferenciranih načina postupanja važno je i kako će se evolucija novih medija i novih načina upotrebe medija odvijati u budućnosti. U naučnom istraživanju medija $u$ više tačaka još vlada nejasnoća. Gotovo fascinantne vizije novih medija iz 90-tih su u međuvremenu potonule usled određenog razočarenja $\mathrm{u}$ analize. Postojeća shvatanja su polazila od sveobuhvatne pretpostavke da i demonizovanje dejstva masovnih medija i ogromna pozitivna očekivanja od novih medija za osnovu imaju pojednostavljeno i jednostrano shvatanje, koje se odnosi pre svega ili čak isključivo na problematiku forme medija. Diferenciranije i realističnije procene novih medijskih razvoja moraju, osim toga, imati u vidu procese kontekstualno fiksiranog subjektivnog rukovanja medijima. To važi i za odnos medijske kompetencije i novih formi medijske komunikacije označenih kao Web 2.0. Sa jedne strane se postavlja zadatak da se opišu mogućnosti stvorene novim formama medija. Ali ni u kom slučaju se medijske kompetencije ne mogu jednostavno izvesti iz ovih novih mogućnosti. Uz to su analize procesa i okolnosti korišćenja medija neophodne za realizaciju principijalno datih potencijala. U medijsko-sociološkoj diskusiji se ovi potencijali opisuju kao interaktivnost. Veoma interaktivni mediji nude široke mogućnosti aktivnog učešća korisnika u oblastima informacije, komunikacije i zabave. Postojeći podaci o konkretnom korišćenju ponuda Web-a 2.0 pokazuju da spram jednog relativno malog procenta aktivnih učesnika stoji veliki broj recipirajućih korisnika. Da li Web 2.0 stvarno predstavlja „Mitmach-Netz“, sa stanovišta korisnika se mora označiti makar znakom pitanja. Ipak se promena medija, označena kao interaktivnost novih medija, ne može poreći, a ona ima uticaj na usvajanje medijskih kompetencija. Ovi uticaji pojačavaju, tako glasi pretpostavka, tendenciju da se medijska kompetencija usvaja u procesima samosocijalizacije. Novi mediji stavljaju medijsku pedagogiju pred zadatak da promisli o pretpostavkama, procesima i uslovima usvajanja medijske kompetencije. To bi se moglo desiti kroz diskusiju o odnosu interaktivnosti novih medija i samosocijalizacije. 
Milica Andevski

Spomenka Budić

Olivera Gajić

\section{MEDIA COMPETENCE AND SELF-SOCIALIZATION OF THE CONTEXT NEW MEDIA ${ }^{2}$}

\section{SUMMARY}

The Internet opens the access to media offers that can be individually formed more than other mass media, so we must wonder how to learn new individual methods of dealing with media offers and whether the altered media forms affect the processes of media socialization. These possible impacts will further be viewed as forms of self-socialization.

The concept of self-socialization can be put into various contexts of previous studies of socialization, if it is, as always, aimed at the independence of subjects. Socialization theories can be distinguished by the way in which they measure the aspects of self-socialization and socialization that is realized by some other person (teacher, parent, peers). The more we adopt direct external possibilities of impact, instructions and intervention on subject, the more processes of socialization realized by another person are emphasized. In contrast to this, the more we emphasize the processes of self-organization, self-regularization and self-constructiveness, the more we have the aspects of self-socialization in mind.

Relationship between self-socialization and the use of media, i.e. media competence, is not new, and in the broad field of examining the mass communication it is described and discussed in details. The subjects are not, as various studies oriented towards reception show, passively and helplessly left to media impacts, but they independently handle media offers. This aspect of media socialization could be performed step by step, according to studies of the media aimed at media coercion and effects.

Precisely in the field of socialization in dealing with the new media, we can now indicate to the fact that new generations are increasingly being left to themselves and, therefore, they have been socializing on their own. The use of media as self-socialization, means that those who are socialized, they manage the choice of media and media content, relatively autonomously decide on time and place of accessing the media and independently construct the meaning of media content in reception process, which is also reflected by independent development of meaning. This also refers to the aspect of interactivity of the new media, i.e. individual disposition with media content. From this it follows that: possibility of intervention and organization for users increases the autonomy in handing the media. Unlike the older, as it is frequently said, the younger generation claims more value to determining, all by itself, which media content, when and in what form it will handle.

The new media set the task to media pedagogy to think about assumptions, processes and terms of adopting media competence. That could happen through the discussion about the relationship between interactivity of new media and self-socialization.

Key words: new media, self-socialization, media pedagogy, media competence, Internet

$2 \quad$ The paper is a result of the research within the Project Digital media technologies and socially-educational changes (Project no. 47020), which is implemented with financial support of the Ministry of Science and Technological Development of the Republic of Serbia, for the period 2011-2014. 


\section{LITERATURA}

Andevski, M., Vučković, Ž., (2012) Prolegomena za kritičku pedagogiju medija. Visoka škola strukovnih studija za obrazovanje vaspitača Vršac, Filozofski fakultet, Novi Sad.

Baacke, D., (1996) Medienkompetenz als Netzwerk. Reichweite und Fokussierung des Begriffes, der Konjunktur hat. U: Medien praktisch 20, 1996, S. 4-10.

Beißwenger, M., (2005) Interaktionsmanagement in Chat und Diskurs. In: Storrer,A., (Hrsg.) Chat-Kommunikation in Beruf, Bildung und Medien. Stuttgart: Ibidem-Verlag, S. 63-87.

Bucher, H. J., (2004) Online-Interaktivität-ein hybrider Begriff für eine hybride Kommunikations- form. In: Bieber, C., Leggewie, C., (Hrsg) Interaktivität. Ein transdisziplinärer Schlüsselbegriff. Frankfurt/New York: Campus Verlag, S. 132-167.

Chomsky, N., (1972) Aspekte der Syntax-theorie. Frankfurt/M.: Suhrkamp.

Dollase, R., (1999) Selbstsozialisation und problematische Folgen. In: Fromme, J., Kommer, S., Mansel, J., Treumann, K.P., (Hrsg.) Selbstsozialisation, Kinderkultur und Mediennutzung. Opladen: Leske\&Budrich, S. 23-42.

Fromme, J., Kommer, S., Mansel, J., Treumann K.P., (Hrsg.)(1999) Selbstsozialisation, Kinderkultur und Mediennutzung. Opladen: Leske\&Budrich.

Gapski, H., Gräßer, L., (2007) Medienkompetenz im Web.2.0 - Lebensqualität als Zielperspektive. In: Gräßer, L./Pohlschmidt, M., (Hrsg.) Praxis Web 2.0. Potenziale für die Entwicklung von Medienkompetenz. Düsseldorf/München: KoPäd, S. 11-34.

Habermas, J., (1995) Notizen zur Entwicklung der Interaktionskompetenz. Frankfurt/M.: Suhrkamp.

Hurrelmann, K., (2002) Selbstsozialisation oder Selbstorganisation? Ein sympathisieren- den, aber kritischer Kommentar. Zeitschrift für Soziologie der Erziehung und Sozialisation, Jg.22, Heft 2, S. 155-166.

Kohlberg, L., Levine, C., Hewer, A., (1983) Moral stages:A current formulation and a response to critics. In: Meacham, .A.,(Hrsg.) Contrabutions to Human Development, Vol. 10. Basel.

Krämer, S., (2000) Subjektivität und neue Medien. Ein Kommentar zur Interaktivität. In: Sandbothe, M., Marotzki, W., (Hg.) Subjektivität und Öffentlichkeit. Kulturwissenschaftliche Grundlagenprobleme virtueller Welten. Köln: Herbert von Halem. S. 102-116.

Krappmann, L., (2002) Warnung vor dem Begriff der Selbstsozialisation.Zeitschrift für Soziologie der Erziehung und Sozialisation, Jg. 22, Heft 2, s. 178-185.

Luhmann, N., (1996) Die Realität der Massenmedien (1995) 2.erw.Aufl.Opladen WD Verlag. Matzat, U., (2005) Die Einbettung der Online-Interaktion in soziale Netzwerke der OfflineWelt. In: Jäckel, M./Mai, M., (Hrsg.) Online-Vergesellschaftung? Mediensoziologische Perspektiven auf neue Kommunikationstehnologien. Wiesbaden: VS Verlag für Sozialwissenschaften, S. 175-199.

Mehler, A., Sutter, T., (2008) Interaktive Textproduktion in Wiki-basierten Kommunikations - systemen. In: Zerfa $\beta$ A., u.a. (Hrsg.) Kommunikation, Patizipation und Wirkungen im Social Web. Band 1:Grundlagen und Methoden:Von der Gesellschaft zum Individuum. Köln: Herbert von Halem. S. 267-300.

Neuberger,C.,(2007) Interaktivität, Interaktion, Internet. Publizistik, Jg.52, Heft, S.33-50.

Rörig, H., (2006) Die Mär vom Mehr. Strategien der Interaktivität. Begriff, Geschichte, Funktionsmuster. Berlin: Lit-Verlag.

Süss, D., (2004) Mediensozialisation von Heranwachsenden: Dimensionen-Konstanten- Wandel. Wiesbaden: VS Verlag für Sozialwissenschaften. 
Sutter, T., Charlton, M., (2002) Medienkompetenz - einige Anmerkungen zum Kompetenzbegriff. In: Groeben, N., Hurrelmann, B., (Hrsg.) Medienkompetenz. Voraussetzungen, Dimensionen, Funktionen. Weinheim: Juventa, S. 129-147.

Theunert, H., (1999) Medienkompetenz. Eine pädagogisch und altersspezifisch zu fassende Handlungsdimension. In: Schell, F., Stolzenburg, E.,Theunert, H.,(Hrsg.) Medienkompetenz: Grundlagen und pädagogisches Handeln. München: KoPäd, s. 50-59.

Tipp, A., (2008) Doing being present. Instant Messaging aus interaktionssoziologischer Perspektive. In: Stegbauer, C., Jäckel M., (Hrsg.) Social Software. Formen der Kooperation in computerbasierten Netzwerken. Wiesbaden: VS Verlag, S. 175-193.

Veith, H.,(2002) Sozialisation alsrefleksive Vergesellschaftung. Zeitschrift für Soziologie der Erziehung und Sozialisation, Jg. 22, Heft 2, S. 167-177.

Zinnecker, J., (2000) Selbstsozialisation - Essay über ein aktuelles Konzept. Zeitschrift für Sozialisationsforschung und Erziehungssoziologie, Jg. 20, Heft 3, s. 272-290. 